\title{
Conflicted Representations: Language, Lexicography, and Johnson's “Langscape” of War
}

Lynda Mugglestone

University of Oxford

\section{Abstract:}

Books, as Samuel Johnson stated in 1754 in his Dictionary of the English Language neared completion, always exert "a secret influence on the understanding" so that the reader is informed in both overt and covert ways. Reference works, he stressed, were no exception. As this essay explores, Johnson's precepts prove equally illuminating for his own work, and his representations of war and conflict. On one level, his Dictionary of 1755 is a source of formal exposition in which the meaning of war is anatomized across a range of entries. On another, those who consult its pages are presented with war as an ethical or socio-moral problem, freighted with meanings of a very different kind.

\section{Keywords:}

Samuel Johnson, lexicography, eighteenth-century lexicology

A "war word," according to the Oxford English Dictionary (henceforth $O E D$ ) is a distinctively twentiethcentury phenomenon. ${ }^{1}$ When it first appeared in the OED Supplement of 1933 edited by William Craigie and Charles Onions, evidence of usage was traced to the preceding year. "We have the war-word Minnie for the German minenwerfer," a citation from Ernest Weekley's Words and Names (1932) confirmed. ${ }^{2}$ Antedatings are, however, not difficult to find. Both "war words" and "war phrases," for example, elicited regular comment in the Daily Mail and the Daily Express in $1916 .{ }^{3}$ Andrew Clark's monumental 
collection "English Words in War-Time," compiled between 1914 and 1919, takes usage back to $1914 .{ }^{4}$ He documented, too, a range of other constructions -- "trench language," "trench dictionary," or "trenchese" - in which war and words unite. "Atkinese" - a variety deemed distinctive of "Tommy Atkins," the prototypical British soldier-is a further example. For the First World War, words for words about war (or specific aspects of it) exhibit marked productivity.

For the eighteenth century, in contrast, questions about linguistic representation in this domain remain largely unexplored. "War-words," and a metalanguage of words for words about war, pace the OED, remain absent. The diction of "trench warfare" is, of course, anachronistic, though "trenching war" (which, in a citation from Shakespeare's Henry IV, appears in Johnson's Dictionary under "channel, v."), offers an interesting early precedent. ${ }^{5}$ Nevertheless, the attempt to locate a "langscape" of eighteenthcentury conflict - whether with reference to its material culture or its framing ideologies - provides considerable explorative potential. War, as both John Richardson and Jeremy Black argue, can be seen as a defining property of this period. ${ }^{6}$ Attendant discourses of power and conquest, as the first part of this essay documents, can be used to posit wider questions about nation and identity in which language itself is a key element, not least in relation to issues of subordination and transnational control. The interventionist role that the lexicographer might assume in the world of words informs, as we will see, other topical figurations where war, imperialism, and language (as well as national defense) are often aligned. The rise of the eighteenth-century reference book might have been depicted, as by Samuel Richardson, as a potentially reductive exercise. "Our study," as Richardson wrote in a letter in 1750, seems, paradoxically, "to get knowledge without study," such that "a smattering is now almost all that is aimed at." ${ }^{7}$ Nevertheless, dictionaries, like language history more widely, can also reveal a form of linguistic ecology, documenting the ways in which language and its representation intersect with prevailing aspects of the physical, social, or psychological environment, and in which, as Alwin Fill observes, both "conflictual or peaceful contact" make their mark. ${ }^{8}$ 
War, and its accompanying metalanguage, early appeared as a staple element in eighteenth-century lexicography, though its cursory treatment could, arguably, validate the criticisms Richardson advanced. As in the anonymous Glossographia Anglicana Nova of 1707, it forms one of fourteen subdivisions on the title page (to which are added the "terms ... of all other Arts and Sciences"). Nathan Bailey's Dictionarium Britiannicum of 1736 provided some sixty subcategories, among which "Military Affairs" and "Gunnery" assumed a nominal place. The Soldier's Pocket-Dictionary (1797) might offer a plurilingual panorama of war terms, documented in six languages, but, as lamartino notes, its focus was restricted to functional translation rather than detailed explication. ${ }^{9}$

War, too, and its potential within lexicography, nevertheless prompts Samuel Johnson's earliest surviving comments on commercial dictionary-making. "You may remember I have formerly talked with You about a military Dictionary," he wrote to the publisher Edward Cave in 1738. "The Eldest Mr. Macbean who was with Mr. Chambers has very good Materials for such a Work. . . I think the terms of War and Navigation might be comprised with good explanations in one 8 vo pica which he is willing to do for twelve shillings a Sheet." ${ }^{10}$ A work that facilitates "reading of war in books" will, Johnson suggests, guarantee an audience. That words for and about war form a significant part of the collective enterprise that underpinned Johnson's own Dictionary is, therefore, unsurprising.

Johnson's engagement with the language of war can, however, move beyond the formal specification of word and definition in intriguingly fruitful ways. "Books," as he wrote in 1754 during the final stages of editing his Dictionary, have "a secret influence on the understanding", while readers, Johnson pointed out, can be informed in covert as well as overt ways. Via such processes of indirection, "[h]e that entertains himself with moral or religious treatises" will "imperceptibly advance in goodness," he commented. Meanwhile, "ideas which are often offered to the mind will at last find a lucky moment when it is disposed to receive them" ${ }^{11}$ Reference works are no different, such that "He that reads books of science [i.e., knowledge], though without any fixed desire of improvement, will grow more 
knowing." ${ }^{12}$ Seen in this light, Johnson's Dictionary can, of course, inform about the language of war across a host of words and senses. But, courtesy of other modes of reading, those who consult its entries can also be led to engage with war as an ethical or socio-moral problem, freighted with meanings of a very different kind.

\section{Conflicted Spaces: Tropes of War and the Language of the Nation}

War offers, in relation to language, a wide range of interpretive possibilities. Figurations of language and nation, for Johnson as for a range of other writers at this time, could, for example, invoke their own tropes of conflict, as well as conquest and defeat. "Nation," in Johnson's Dictionary, is defined at least in part by its speakers and the language they use ("a people distinguished from another people; generally by their language, original, or government"). But, as Edward Phillips, Milton's nephew, had stated in his New World of Words (1658), English was characterized, too, by "invasion" and the subsequent settlement of an "army of forraign words". The legitimate territories of language were a well-established source of anxiety. "If too many Foreign Words are pour'd in upon us, it looks as if they were design'd not to assist the Natives, but to Conquer them," as John Dryden observed forty years later. ${ }^{13}$ Lexical migration could be seen as covert colonization, while discourses of power-and potential disempowerment-are prominent. "The Laws of forein Conquests usually extend to Letters and Speech," John Wilkins warned. ${ }^{14}$ Dryden, like Wilkins, urged caution as well as control

That war in the eighteenth century was by no means metaphorical served to heighten concerns of this kind. Britain, as Addison noted in 1711 with patriotic pride, was indeed in the ascendant in the War of Spanish Succession, a conflict then in its tenth year, and in which Britain was fighting both France and Spain. Nevertheless, language arguably told a different story. As Addison demanded, "When we have won Battels which may be described in our own Language, why [are] our Papers filled with so many 
unintelligible Exploits, and the French obliged to lend us a Part of their Tongue before we can know how they are Conquered?"15 Soldiers, whose role was to repel, were instead deemed instrumental in linguistic submission (and diffusion): "Our Warriors are very Industrious in propagating the French Language, at the same time that they are so gloriously successful in beating down their Power." If, Janus-like, war was seen as operating on two fronts while victory and defeat disturbingly coexist, at stake was the spectre of a new Norman Conquest in which English itself might be invaded and overruled. French, as well as France, can carry out enemy action.

Johnson's own work undeniably shares some of this historical as well as ideological positioning. By 1746, when he signed the contract for the Dictionary, Britain had, for example, been subject to an attempt at a far more literal French invasion, thwarted in 1744 by the deterrent effect of bad weather as well as a large British fleet positioned in the English Channel. The Seven Years' War, formally declared against France in 1756, was already brewing as the Dictionary was being composed. "My uncle is continually employed in computing the year in which this kingdom is to become a province to France," a letter in The World declared. ${ }^{16}$ Works such The Danger of Great Britain and Ireland Becoming Provinces to France (written in 1746 by Simon Smith and Richard Munn) revealed similar concerns. "Province": 'A conquered country; a country governed by a delegate," the relevant entry in Johnson's Dictionary explains.

For Johnson, these issues of identity, subordination, and autonomy would overtly extend to language as well as nation. That the British should "be reduced to babble a dialect of France" was, as he declares in his preface to the completed Dictionary, a circumstance to be avoided. ${ }^{17}$ Johnson constructs a dystopian linguistic narrative that mirrors, in effect, the positioning of "province" against "nation," which popular figurations of Anglo-French relations in the mid-1750s display. Meanwhile "dialect" invited active consideration of a reformed hierarchical positioning in which English, as erstwhile "language," has lost place. 
The problematic nature of Anglo-French relations, in language, life, and lexicography, is likewise apparent in the deliberations of Philip Dormer Stanhope, Lord Chesterfield, Johnson's patron for the Dictionary, whose involvement spanned 1746 to 1754 . Writing in Dodsley's journal The World in November 1754, Chesterfield placed local and international concerns alongside the agency that Johnson as lexicographer should rightly assume. Tropes of power are overt. Language, as for Dryden, is positioned as a kind of territorial (and imperial) advance. Louis XIV's earlier endeavors on behalf of French are duly noted-“The spreading the French language over most parts of Europe, to the degree of making it almost a universal one, was always reckoned among the glories of [his] reign" - even if, Chesterfield declares, English is now effecting “Conquests' of its own: 'I have . . . a sensible pleasure in reflecting upon the rapid progress which our language has lately made, and still continues to make, all over Europe."

Anxieties that, in any war of words, English might "be overwhelmed and crushed by unnecessary foreign ornaments" still, however, remain pertinent. ${ }^{18}$ Lexicography is, in turn, rendered an adversative as well as documentary process. If, for Chesterfield, Johnson's work is to transcend the "wordbooks" of the past in scope as well as analytical depth, further ambitions are identified in relation to the nation state of words. In the 1747 Plan of a Dictionary, Johnson's military metaphors had, deferentially, placed him as foot soldier to Chesterfield's Caesar. Poised on the borders of the metaphorical New World before his advance into English began, he had indicated his unswerving obedience to Caesar's decree (JEL, 58). In 1754, as Chesterfield's letter confirms, these tropes of individual power were, on one level, reversed. It is Chesterfield who, at least rhetorically, now vows submission to any dictates Johnson cares to issue, offering "a total surrender of all my rights and privileges in the English language, as a free-born British subject, to the said Mr. Johnson, during the term of his dictatorship." Courtesy of the Dictionary, the conquest - and defence-- of the national tongue is, Chesterfield indicates, assumed to be complete. 
Tropes of war, and their linguistic ramifications, remain, as Joan Beal confirms, common elements of eighteenth-century language discourse. ${ }^{19}$ Nevertheless, if we expect Johnson's practice within the Dictionary to exhibit a stalwart French resistance, or a process of categorical rule, we might, like Chesterfield, find ourselves somewhat disappointed. Johnson might, as we have seen, participate at times in both political and linguistic scaremongering, in which the rhetoric of defense and attack is marked. But as he makes plain, the futility of rendering the lexicographer a border guard of discourse, whether in retaining 'fugitives' or repelling 'invaders' is unambiguous. Across the Dictionary attitudes to loanwords, and specifically French loanwords, hence proved both more thoughtful, and responsive to language practice than Chesterfield suggested. Naturalization, deemed at an end by Chesterfield in 1754 , is instead made an ongoing process, in a cline of assimilation that, across a range of entries, is closely linked to the trajectories of use..$^{20}$

In similar ways, the colonial processes that Johnson contemplated with trepidation in the Plan are, famously, not carried out. If Johnson attempts to bring order and clarity to the realm of words, he leaves it for some other "adventurer to proceed farther, to reduce them wholly to subjection, and settle them under laws" (JEL, 58). Johnson, as Jack Lynch notes, clearly "thought a good deal about war," but, here and elsewhere, he by no means displays an unqualified belief in its heroic or remedial potential. ${ }^{21}$ Seen in this light, war as linguistic conquest can indeed be part of Johnson's expectations in the Plan. Yet, as his 1755 preface confirms, expectations are, by their nature, fallible (JEL, 104-05). Scruples about power as an imposed force, against the consensus of common law, pervade Johnson's writing in the dictionary years. ${ }^{22}$ The legal metaphors that, in the 1755 preface, displace those of military endeavor as used in the Plan provide their own illumination in this respect.

\section{Representing War in Johnson's Dictionary}


War, in relation to these framing metaphors, can therefore seem to display a quintessential Johnsonian "doubleness", such that motifs of power and conquest are advanced and then withdrawn. Johnson's interest in language and war, as documented across the Dictionary is, in some ways, similar. On one hand, if regarded as a register of situational variety, war required elucidation in ways that return us to considerations of the Dictionary as an entirely pragmatic artefact. "It seems necessary to the completion of a dictionary design'd not merely for critics but for popular use," as Johnson notes in the 1747 Plan, '"that it should comprise, in some degree, the peculiar words of every profession." In this respect, meaning is denotative: "the terms of war and navigation should be inserted so far as they can be required by readers of travels, and of history." On the other, however, Johnson's tactics in writing war in the Dictionary, embedded in citational evidence as well as individual entries, can, incrementally guide readers toward other, more complex, forms of understanding.

Johnson's reading, undertaken as part of the processes of lexicography, underpins both. "If the language of theology were extracted from Hooker and the translation of the Bible; the terms of natural knowledge from Bacon; the phrases of policy, war, and navigation from Raleigh; the dialect of poetry and fiction from Spenser and Sidney; and the diction of common life from Shakespeare, few ideas would be lost to mankind, for want of English words, in which they might be expressed," he stated, for example, in 1747 (JEL, 96). Johnson's identification of Walter Raleigh as a prime evidential resource in this respect was based on the latter's status as both soldier and adventurer, and on works such as Raleigh's Apologie for his Voyage to Guiana (written ca.1617 and published in 1650) or his History of the World (originally published in 1614). "War" itself, in the Dictionary, is hence defined by means of Raleigh's authorizing voice: "War may be defined the exercise of violence under sovereign command against withstanders; force, authority, and resistance being the essential parts thereof." As Raleigh continues, "Violence, limited by authority, is sufficiently distinguished from robbery, and the like outrages; yet consisting in relation towards others, it necessarily requires a supposition of resistance, 
whereby the force of war becomes different from the violence inflicted upon slaves or yielding malefactors." ${ }^{3}$ "Withstander," glossed by Johnson as "an opponent; resisting power," and illustrated in the same citation, gains a further entry in the Dictionary, courtesy of Raleigh's use. Similar evidence from Raleigh appears under "stronghand," defined as "force; violence": "They wanting land wherewith to sustain their people, and the Tuscans having more than enough, it was their meaning to take what they needed by stronghand". "Demi-culverin" (a type of gun), provides a further example.

A further imported citation from Raleigh, used under "nation," is similarly illuminating. Here, issues of language and identity, conquest and defeat, were again made overt: "If Edward III had prospered in his French wars, and peopled with English the towns which he won, as he began at Calais driving out the French, his successors holding the same course, would have filled all France with our nation." Plain, too, is the fact of historical contingency, in ways which affect the spread of nation and language alike.

How useful Raleigh was, in reality, in registering the language of war for Johnson is, however, a matter of debate. Johnson was undoubtedly an attentive reader of Raleigh, in ways that, in practice, informed a wide range of non-military entries across the Dictionary, including "descry" and "delineate," "solicitude" and "sublimity," or "sunset" and "supercelestial." ${ }^{24}$ By extension, Johnson's scrutiny of the "phrases ... of war" was consciously supplemented in a variety of ways. He makes extensive use, for instance, of an otherwise unnamed "Military Dictionary," probably the anonymous Military Dictionary. Explaining all difficult terms in martial discipline fortification and gunnery . . by an officer who served several years abroad that, originally published in 1702 , was reissued in 1708 . This forms the basis for a number of eminently factual entries, as for words like "crowfoot" or "petard":

Crowfoot. n.s. A caltrop or piece of iron with four points, two, three, or four inches long; so that, whatever way it falls, one point is up. It is used in war for incommoding the cavalry. Military Dict. 
Petard. n.s. A petard is an engine of metal, almost in the shape of an hat, about seven inches deep, and about five inches over at the mouth: when charged with fine powder well beaten, it is covered with a madrier or plank, bound down fast with ropes, running through handles, which are round the rim near the mouth of it: this petard is applied to gates or barriers of such places as are designed to be surprized, to blow them up: they are also used in countermines to break through into the enemies galleries. Military Dict.

In the practices Johnson adopts, citations of this kind act as appropriated definitions, nesting other examples of lexicographical authority within the Dictionary in ways that obviate the need for further interpretation. As under petard, it is the explanatory value of the Military Dictionary, rather than Johnson himself, that thereby elucidates Shakespeare's "'Tis the sport to have the engineer / Hoist with his own petard," in a further illustrative citation Johnson chose to include. We can see a similar process under "demi-culverin." Here, Raleigh, as already indicated, provides supporting evidence. But it is the Military Dictionary that is given the right of definition: "A gun four inches and six eights diameter in the bore, ten foot one third in length. It carries a ball four inches four eight parts diameter, and twelve pounds eleven ounces in weight."

Other source texts intervene, too. "Poniard," "a dagger; a short stabbing weapon," is illustrated by citations that derive from Johnson's reading of Shakespeare, Peacham, and Dryden. "Arsenal," defined as "a repository of things required for war," is illustrated by a quotation from Addison, and "barricade," "a fortification ... any thing fixed to hinder entrance," by one from Bacon. Johnson's probing of sense and sub-sense (again from a range of source texts) likewise included the specification of distinctive military applications for a range of common words. If "brisk," "petulant," and "smart," are, for instance, all identified as viable interpretations for the "common sense" of "alert," it is the qualities of being "watchful" and "vigilant" that inform its "military sense"." ${ }^{25}$ Entries for "powder (n.)," "range (v.)," and "bicker (v)" are similar. In each, Johnson documents available polysemies, alongside the intricate 
patterning of war in English use, such that "bicker" is "to skirmish; to fight without a set battle; to fight off and on" (illustrated by Sidney and Shakespeare) and "powder" acts as a contraction for "gunpowder" (as attested by Addison and Hayward) while also designating "sweet dust for the hair." Johnson draws careful attention, too, to ongoing patterns of change, such that a "mine" might traditionally refer to "a cavern dug under any fortification that it may sink for want of support," but, in this domain, its "modern" use is different: "In modern war, that powder may be lodged in it, which being fired at a proper time, whatever is over it may be blown up and destroyed." ${ }^{26}$ Likewise, while "bestride" in 1755 had been identified as "used sometimes of a man standing over something which he defends" (sense 4), the "present mode of war," as Johnson clarifies in a redrafted definition in 1773, "has put this sense out of use." Other relevant changes in the fourth edition of the Dictionary for such terms as "artillery," "bivouac," "buff," and "chief" (among others) reveal Johnson's continued interest and engagement in diction of this kind. ${ }^{27}$ Defining "artillery" (sense 1 ) as merely "weapons of war" (as in 1755) is now judged inadequate; instead Johnson adds the interpretative gloss "always used of missive weapons." New military senses of "captainship" are added, too.

Johnson clearly continued to explore war and its diction such that his lexicographical work presents us with a level of information that other eighteenth-century dictionaries conspicuously lack. Particularly illuminating, however, is Johnson's empiricist engagement with usage across a spectrum of writers. If, as Robert DeMaria contends, reading is, in general, an activity that leaves no traces, this is, as he documents, demonstrably untrue in relation to the entries in Johnson's Dictionary. ${ }^{28}$ Instead, each entry is underpinned by a process of documentary reading by which Johnson gathered the evidence on which both headwords and sub-senses were variously derived. Figure 1 is, for example, taken from Johnson's marked-up text of the eighth edition of Robert Burton's Anatomy of Melancholy (1676), in a passage that focuses on war. As this illustrates, quotations deemed useful for the Dictionary were delimited by vertical or diagonal lines, while the relevant headwords (here "griper" and "hotspur") under which such 
information is to be ordered were underlined. The initial letter for the entry that might be written was capitalized and placed in the margin. ${ }^{29}$ Descriptive processes of this kind self-evidently disrupt the martial tropes of lexicography to which Chesterfield had earlier inclined. Instead, as Johnson stresses, it is, in reality, the collective evidence of citations of this kind in which ultimate authority in the Dictionary resides. "I have studiously endeavoured to collect examples and authorities," he notes; it is in "these authorities, on which the credit of every part of this work must depend" (JEL, 95, 55).

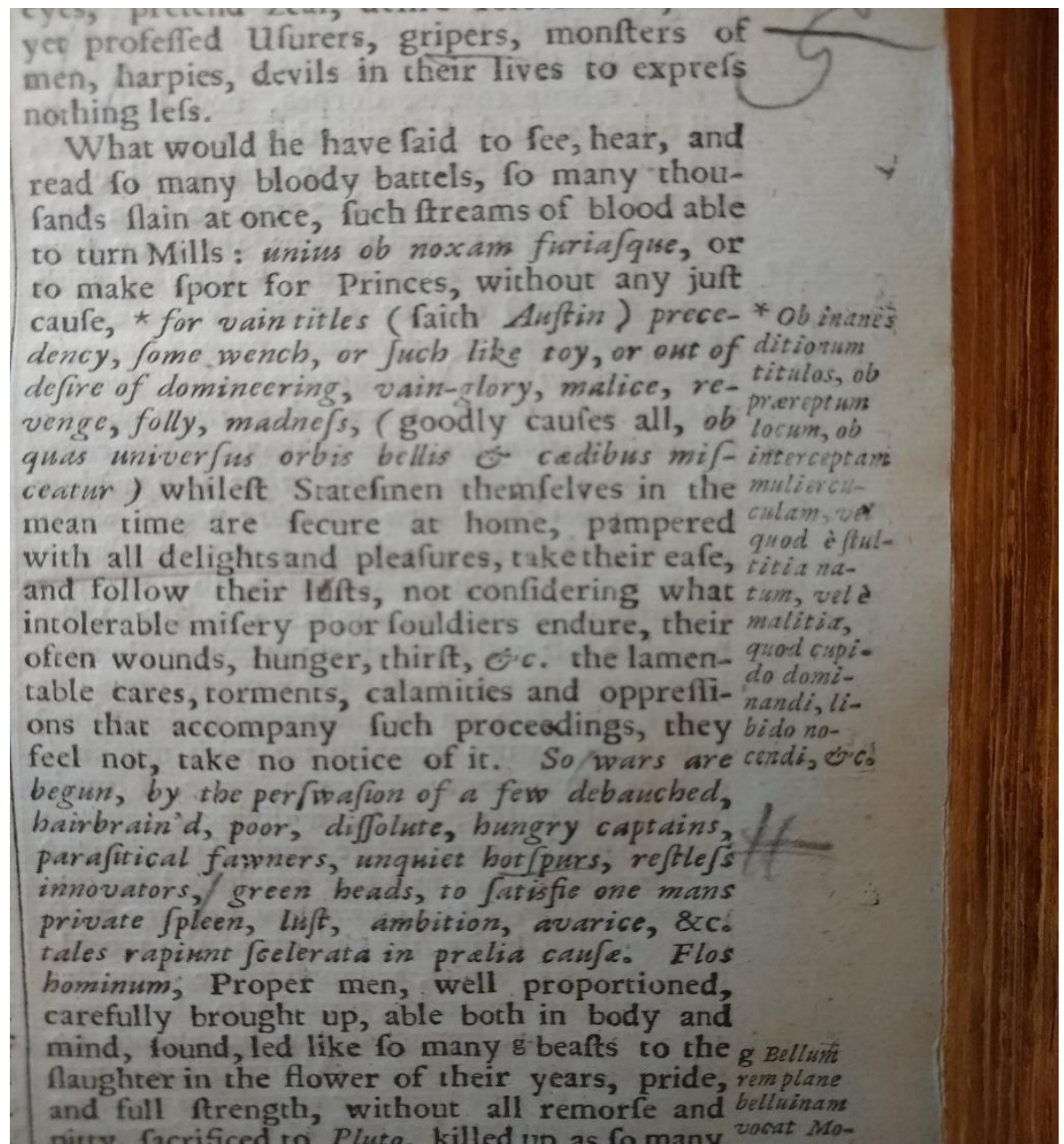


Figure. 1. Samuel Johnson's annotated copy of Robert Burton's Anatomy of Melancholy, $8^{\text {th }}$ edition (1676), p.17.

Johnson treated information from other dictionaries for "war words" with marked distrust if he could not, in his own reading, confirm that information with direct evidence of usage. John Richardson has, rightly, pointed to Johnson's "deep-seated skepticism about war" but a similar skepticism extended to some of its lexical forms and the validity that these possess in English use..$^{30}$ "Belligerate," a verb given in Bailey's Universal Etymological English Dictionary (1721) as meaning "to make War," is simply excluded. "Belligerous" which, according to other dictionaries, signifies "waging war," or "bellipotent," defined as "puissant, mighty in war" were conversely distanced by the appended label "Dict," (for "Dictionary"). Similar is e.g. "dimication," used to signify "a battle; the act of fighting." In Johnson's schemata of representation, all thereby lack authority. If readers of the Dictionary are to gain lexical and semantic knowledge, this should, as Johnson makes plain, have a verifiable provenance -- and an authority that extends beyond the inclinations of an individual lexicographer.

What and how Johnson reads, and the evidence he finds, can, however, lead to other significant aspects of interpretation. "If we cannot deduce the nature of a Dictionary from the condition of the author, we may deduce the condition of the author from the nature of the Dictionary," as Ephraim Chambers had provocatively stated in $1728 .{ }^{31}$ Johnson's own skepticism about astrology and superstition, alongside the skepticism that this elicits, is, as DeMaria has demonstrated, easily deducible by means of a close examination of relevant dictionary citations. ${ }^{32}$ Johnson's stance on faith, and the established truths of Christianity, is equally perceptible, whether in definitional strategies or the evidence he chose to include under e.g. "crucifix" or "miracle." As DeMaria has persuasively argues, Johnson's evidential processes of collecting and selecting can, in this light, contain meanings of their own, variously giving, or denying, 
weight to particular tenets or beliefs. Of special interest in this context are therefore the values that war can acquire. War might, in popular use, readily collocate with "play" or "game," terms that, as Johnson suggested in 1771, when revising the Dictionary for the fourth edition, are "opposed to earnest or seriousness" ${ }^{33}$ Likewise, if contemplated in general terms, it is, as he commented, easy to reduce war to a celebratory if reductive narrative, by which words such as "proclamation," "army," "battle," and "triumph" occur in swift succession. Yet Johnson's consciousness of "evil" also exists as a further, and more pertinent, collocate is incontrovertible, such that possible "splendour" is displaced in favor of that which is, of its nature, replete with "bad qualities ... not good" ("evil" (a.), sense 1):

It is wonderful with what coolness and indifference the greater part of mankind see war commenced. Those that hear of it at a distance, or read of it in books, but have never presented its evils to their minds, consider it as little more than a splendid game; a proclamation, an army, a battle, and a triumph.

As the Dictionary suggests, Johnson's interest in collocation, and the wider meaning of war, was, in fact, evident long before he penned his politically polemical Thoughts ... on Falkland's Islands as cited above. War, and references to war, unsurprisingly, of course, occur across thousands of entries in the Dictionary. It can be "merry," as in a war of words between Shakespeare's Beatrice and Benedict, whereby battle, in a citation that Johnson deploys under "conflict" as well as "skirmish," is entirely metaphorical. ${ }^{34}$ It can, intriguingly, also be "nymphish," "relating to nymphs; ladylike," as in a citation from Drayton that Johnson added to the fourth edition of $1773 .{ }^{35}$ War is likewise made a locus of the "bravery" of "noble thanes," in a citation that appears under "day" and is drawn from Macbeth, a play in which conflict of various kinds by no means has a happy outcome. National pride makes its own appearance, as in the reference, deriving from Bacon and given under "again," to the "brave military people ... in England, Scotland, and Ireland." We also find reference to war as something that, ideally, can be ruled and lawful, even though its actions can be violent and disruptive. We might look at, say, Johnson's entry for "discipline," for which the third sense, defined as "military regulation," is illustrated 
by his reading of Richard III: "This opens all your victories in Scotland, / Your discipline in war, wisdom in peace." ${ }^{36}$ Similar is "denunciation," under which a further quotation from Bacon states that "in a denunciation or indiction of a war, the war is not confined to the place of the quarrel, but is left at large." A citation from Davenant added under "one" in 1773 (sense 13) amplifies meanings of this kind: "In democratical governments, war did commonly unite the minds of men; when they had enemies abroad, they did not contend with one another at home." Johnson's historical references to war are, we should note, often documentary and neutral. For instance, we might consider Dryden's "A time of war at length will come, / When Carthage shall contend the world with Rome," which Johnson made use of under "contend," or the statement (again based on classical history, and taken from Bacon) that "the Romans, when commanders in war, spake to their army, and styled them, My soldiers," which Johnson decided to quote under "commander," defined as "he that has the supreme authority; a general; a leader; a chief." 37

Nevertheless, the attentive reader of Johnson's citations will probably notice his preference for texts that present the meaning of war negatively rather than positively, and that impose ideological distance, rather than affirmation or emulation. This is clear for civil war, where the Dictionary systematically reflects disapproval for the national disorder that must ensue. Documenting "aslake," Johnson is drawn to Spenser's use in the context of "continual, cruel civil war" that "no reason can aslake." Under "anew," Johnson is drawn to war's miseries: "The miseries of the civil war did, for many years, deter the inhabitants of our island from the thoughts of engaging anew in such desperate undertakings," supported by a citation from Addison's Freeholder (number 28). It is "evil" with which civil war is overtly paired under "heighten," while, courtesy of a citation from Dryden, it injures the body of the nation under "bruise":

I since have labour'd 
To bind the bruises of a civil war,

And stop the issues of their wasting blood. ${ }^{38}$

"From a civil war, God of his mercy defend us, as that which is most desperate of all others," Bacon exhorts under "civil." Other negative representations appear under "conditionally," "correctness," as well as under "guise," "peep," and "pure." Across the Dictionary, the moral and political failings of civil war are unambiguous.

King Charles, by virtue of other aspects of Johnson's reading, can be made to voice his own concerns, as under "embroil": "I had no passion, design, or preparation to embroil my kingdom in a civil war." ${ }^{39}$ The entry for "kingship" is equally illuminating. It depends on a further citation from King Charles: "They designed and proposed to me the new modelling of sovereignty and kingship, without any reality of power, or without any necessity of subjection and obedience." "We know how successful the late usurper was, while his army believed him real in his zeal against kingship; but when they found out the imposture, upon his aspiring to the same himself, he was presently deserted and opposed by them, and never able to crown his usurped greatness with the addition of that title which he passionately thirsted after," South affirms in a further embedded citation in this entry. If dictionaries, as Bejoint stresses, are always didactic texts, a distinctive kind of didactic practice is arguably in evidence in ways that engage both with nation and individual. ${ }^{40}$

Representations of war within the Dictionary, by extension, regularly elide available discourses of heroism, honor, or glory in favor of citations that instead remind us of war's negative effects. We can, of course, be presented, with the image of "kings and heroes resolute in war," courtesy of a citation selected from Phillips under "aerial," or with "the pomp of war"' in "afar," via Johnson's reading of Dryden. Even so, the clustering of negative collocations associated with war that appear across a wide range of entries is interesting. If Johnson's entry for "feat" can, by way of a truncated version of 
Addison, make war a form of inexpressibility-“Our soldiers are men of strong heads for action, and perform such feats as they are not able to express" - it is notable that the "bold feats" referenced in a citation from Spenser are meanwhile contextualized by the cruelty of war: "His feats, and hardy confidence; Full oft approved in many a cruel war." Johnson was, as we know, repeatedly urged to "clip close" or shorten his citations in the interests of saving space in the published text. ${ }^{41}$ Evidence of this kind, where Johnson's shaping of the citation extends beyond the bounds of merely pragmatic illustration for the headword required, is important. "Cruel war" does not need to be mentioned, nor cast its shadow over the "bold feats" that precede.

To read about war in Johnson's Dictionary is likewise to encounter "fearful war" under "diet," and its "dire effects" under "depopulation," and "clash": "Remote thou hear'st the dire effect of war, / Depopulation" (Phillips); "He nobly seiz'd thee in the dire alarms / Of war and slaughter and the clash of arms" (Pope). That war can demonstrate a kind of moral fallibility is equally plain. "Impious war" appears under "aim" and "enlink," and "beastly, madbrained war" under "contumelious," while it is associated with disaster under "criminal," in a citation derived from Johnson's reading of Bacon: "All three persons, that had held chief place of authority in their countries; all three ruined, not by war, or by any other disaster, but by justice and sentence, as delinquents and criminals." Under "hotspur," we find that "Wars are begun by hairbrained dissolute captains, parasitical fawners, unquiet hotspurs, and restless innovators," a quotation Johnson located in reading Burton's Anatomy of Melancholy (and illustrated in figure 1).

The wider impact of war on the nation informs other manifestations such that, rather than eliciting triumph, it is made a source of economic distress, as in the quotations Johnson chose to provide under "compass" and "damage": "You have heard what hath been here done for the poor ... within the compass of one year, and towards the end of a long, expensive war"; "They believed that they were not able, though they should be willing to sell all they have in Ireland, to pay the damages which had been 
sustained by the war." ${ }^{42}$ Under "all-devouring" and "devour," war is presented as an unremittingly destructive force, laying waste the nation: "Secure from flames, from envy's fiercer rage, / Destructive war, and all-devouring age" (Pope); "Our plains, our temples, and our town devour'd; / It was the waste of war" (Dryden). ${ }^{43}$ "War brings ruin where it should amend," we are reminded under "bloodless." Even Raleigh is made to affirm its grievous nature. "Until this can be agreed upon, one main and fundamental cause of the most grievous war is not like to be taken from the earth," he states under "fundamental." He testifies, to similar effect, to "cruel war" under "combustion." 44 Under "on," we might, of course, be offered the prospect of "perpetual peace" by means of Johnson's reading of Richard III. Still, as Johnson's full citation makes plain, peace is also made contingent on the "bloody trial of sharp war," such that conflict and its outcome are undercut by readings that imply violence, uncertainty, and doubt. $^{45}$

Across the Dictionary, the ideological dice are, in effect, loaded in similar ways. Negative spatial metaphors that show nations diminished rather than enhanced by war take their place under "discovery" - "It would be necessary to say something of the state to which the war hath reduced us; such a discovery ought to be made as late as possible" (Dryden)-while the capacity for individual glory, as well as honor, is firmly undercut under "bubble," defined as "Any thing which wants solidity and firmness; any thing that is more specious than real." Johnson's selected evidence in this entry derives, respectively, from Dryden and Shakespeare, hence

War, he sung, is toil and trouble,

Honour but an empty bubble,

Fighting still, and still destroying, 
and

a soldier,

Seeking the bubble, reputation,

Even in the cannon's mouth. (cited from As You Like It)

Under "nonsparing," glossed as "merciless; all-destroying," it is the prospect of individual destruction and injury that is foregrounded, and illustrated by a citation from Johnson's reading of All's Well That Ends Well: "expose / Those tender limbs of thine to the event / Of the nonsparing war." Across a range of entries, war is depicted as uproar, and as a recurrent symbol of disorder and disharmony-see, for instance, Johnson's entries for "clamourous," "cope," or "quake" (v.). Under "clang" (n.), following a micro-narrative Johnson imposes by sequencing citations, we proceed from the onset to the aftermath of conflict, as reflected in the toll of human suffering:

What clangs were heard in German skies afar,

Of arms and armies rushing to the war!

Dryden.

Guns, and trumpets clang, and solemn sound

Of drums, o'ercame their groans. 
Phillips

The violence of war is amplified in the phrasing of definitions provided for "batter": "To beat; to beat down; frequently used of walls thrown down by artillery, or of the violence of engines of war."

Elsewhere, under "bristle" and "brutal," war is deemed a species of unreason that allies us to brutish behavior: see, for example,

Now for the bare pickt bone of majesty,

Doth dogged war bristle his angry crest,

And snarleth in the gentle eyes of peace. (Shakespeare)

That such patterns are intensified rather than diminished in the fourth edition of the Dictionary in 1773 is perhaps unsurprising. ${ }^{46}$ As Johnson had stressed two years earlier, if war "happens but seldom, . . . every man, either good or wise, wishes that its frequency were still less" (PW, 353). "I am at present against war, though it puts the power into my hands, and though such turbulent and naughty spirits as you are, govern all things in times of peace," another new citation from Davenant, added under "govern," affirms. "Most of the censure ... like most of the messages in the Dictionary, is delivered in the illustrative citations," as DeMaria confirms of other aspects of Johnson's lexicographical practice (Language of Learning, 71-72). War, in this light, is an obvious target.

\section{Conclusive Forms?}


Johnson, as Lynch notes, can be recruited only with difficulty to the pacifist cause ("Johnson Goes to War," 128ff.). Even so, a critical probing of war, informed by a sense of its moral complexity, is clear across Johnson's wider writing. War, he stresses, is "the last of remedies" and "the heaviest of national evils, a calamity in which every species of misery is involved" $(P W, 370,395)$. "It is, surely, the duty of those, whose station intrusts them with the care of nations, to avert it from their charge," he recommends: "What can skill or caution be better shown, than preventing such dreadful operations" (370). If dictionaries, as Ladislav Zgusta stresses, are inevitably human as well as factual products that bear the traces "of how the individual lexicographer reacts to the intellectual climate of his time," the moral probing of war that we can discern in Johnson's lexicographical work, and the patterns of reading and selection he undertook in this respect, can emerge as yet another way in which, in characteristic Johnsonian style, fallible "opinion" can be "improved into knowledge." 47

As Zgusta clarifies, dictionaries can, in principle, be either passive or active in processes of this kind. In the former, the lexicographer merely reflects ideologically dominant ideas and assumptions; in the latter, we might detect the lexicographer "pursuing some purposes of his own." Examining comparable evidence of the negative or positive inflection of war within the fully searchable digitized texts available on Early English Books Online via the Text Creation Partnership is, in this light, revealing. ${ }^{48}$ Collocations of "noble" and "war," or "glorious" and war," (both as proximate and non-proximate modifiers) are not difficult to find: "glorious" and "war" yield 638 hits; "noble" and "war" yield 1,088 hits. Nor are accolades to the "pomp" of "war." "Triumph" and "war" offer 586 matches; "honourable war" yields 545 hits. "Cruel war," however, yields 346 matches as a direct collocation, and 1,083 matches in a wider proximity search. "Brutal ... war" is, conversely, rare (17 matches), and "nervous ... war" rarer still (2 matches). "Sharp ... war" is well established (400 matches); "violent . . . war," far less common with 148 hits. For Johnson an interest in war as a socio-moral process as embedded in the Dictionary might therefore indeed reflect his own critical scrutiny of the dubious gains that war brings. Yet, on the other 
hand, as corpus snapshots of this kind suggest, his perspective is, arguably also far more representative of English thinking, and its wider expression in English use, than we might at first suspect. While further critical investigation of this kind is desirable, the "secret influence" of books might, in this light, be both general and particular. War, as for Black and Richardson, is indeed a defining feature of eighteenthcentury life. But its own cultural definition, as embedded in the textual patterns of English use, repeatedly returns us to human consequences in which, qualitatively and quantitatively, glory, conquest, and triumph sit uneasily against the prominence of violence, misery, and ruin

\section{Notes}

${ }^{1}$ See "war-word (n.)," under "war, (n.) 1," OED online at < http://ezproxyprd.bodleian.ox.ac.uk:2355/view/Entry/225589 >.

${ }^{2}$ Ernest Weekley, Words and Names (London: John Murray, 1932), 21.

${ }^{3}$ See C. R., "To the Editor of The Daily Mail," Daily Mail (1 February 1916); O. S. P., "War-Words and Phrases," Daily Mail (1 November 1916); or the discussion of "The new warword 'tank,"' in the Daily Express (25 October 1916).

${ }^{4}$ See $<\underline{\text { wordsinwartime.wordpress.com }}>$, and also Lynda Mugglestone, Words in WarTime: Andrew Clark and the Search for Meaning in WW1 (Oxford: Oxford Univ., forthcoming).

${ }^{5}$ See "channel (v.)," in Samuel Johnson, A Dictionary of the English Language; in which the Words are deduced from their Originals, and Illustrated in their Different Significations by Examples from the best Writers, 2 vols. (London: W. Strahan for J. and P. Knapton, 1755), $4^{\text {th }}$ ed. (1773): "No more shall trenching war channel her fields, / Nor bruise her flow'rets with the 
armed hoofs / Of hostile pacer, Shakesp. Henry Iv. p.i." Unless otherwise specified, all other references to Johnson's Dictionary are to the first edition.

${ }^{6}$ John Richardson, "Literature and War in the Eighteenth Century," Oxford Handbooks Online, at <http://www.oxfordhandbooks.com/view/10.1093/oxfordhb/9780199935338.001.0001/oxfordhb -9780199935338-e-005 >, and Jeremy Black, War in the Eighteenth-Century World (Basingstoke: Palgrave Macmillan, 2012).

${ }^{7}$ Samuel Richardson to Susanna Duncombe, 15 June 1750, in Electronic Enlightenment Scholarly Edition of Correspondence, ed. Robert McNamee, et al. (Oxford: Oxford Univ.), online at <http://dx.doi.org/10.13051/ee:doc/richsaOU0010160a1c >.

${ }^{8}$ See Alwin Fill, "Language Contact, Culture, and Ecology," in The Handbook of Language and Communication: Diversity and Change, ed. Marlis Hellinger and Anne Pauwels (Berlin: De Gruyter, 2008), 177.

${ }^{9}$ G. Iamartino, "Foreign Words in the Kit- Bag: James Willson's The Soldier's PocketDictionary of 1794," in Lexis and Texts in Early English: Studies Presented to Jane Roberts, ed. Christian Kay and Louise Sylvester (Amsterdam: Rodopi, 2001), 143-60.

${ }^{10}$ Samuel Johnson to Edward Cave, 1738, in The Letters of Samuel Johnson, ed. Bruce Redford, 4 vols. (Oxford: Oxford Univ., 1992) 1:21-22.

${ }^{11}$ Samuel Johnson, The Adventurer 137 (26 February 1754), in The Idler and The Adventurer ed. W. J. Bate, J. Bullitt, L. Powell, vol. 2 of The Yale Edition of the Works of Samuel Johnson, gen. ed. Robert DeMaria Jr., et al. (New Haven: Yale Univ., 1963), 491.

${ }^{12}$ See “science (n.)," in Johnson's Dictionary: “1; Knowledge," "2. Certainty grounded on demonstration." 
${ }^{13}$ John Dryden, "“The Dedication to the Aeneis to the Earl of Mulgrave," vol. 3 of The Poems of John Dryden, ed. James Kinsley (Oxford: Oxford Univ., 1958), 1,060.

${ }^{14}$ John Wilkins, An Essay towards a Real Character, and a Philosophical Language (London: Samuel Gellibrand, 1668), 6.

${ }^{15}$ Joseph Addison, The Spectator 165 (8 September 1711), in The Spectator, ed. Donald Bond, 5 vols. (Oxford: Oxford Univ., 2014), 2:149-50.

${ }^{16}[$ Richard Owen Cambridge] to The World, in The World 102 (12 December 12 1754): 597.

${ }^{17}$ Samuel Johnson, Johnson on the English Language, ed. Gwin J. Kolb and Robert DeMaria Jr., vol. 18 of The Yale Edition of the Works of Samuel Johnson, gen. ed. DeMaria, et al. (New Haven: Yale Univ., 2005), 108-09, hereafter referred to as JEL.

${ }^{18}$ [Philip Dormer Stanhope] to The World, in The World 100 (28 November 1754): 603.

${ }^{19}$ Joan Beal. "“Á la Mode de Paris': Linguistic Patriotism and Francophobia in Eighteenth-Century Britain," in The Languages of Nation: Attitudes and Norms, ed. Carol Percy and Mary Catherine Davidson (Bristol: Multilingual Matters, 2012).

${ }^{20}$ See Johnson, JEL: “Academies have been instituted, to guard the avenues of their languages, to retain fugitives, and repulse intruders; but their vigilance and activity have hitherto been vain" (105). See Lynda Mugglestone, “The End of Toleration? Language on the Margins in Samuel Johnson's Dictionary of the English Language," in Standardising English: Norms and Margins in the History of the English Language, ed. Linda Pillière, Wilfred Andrieu, Valérie Kerfelec and Diana Lewis (Cambridge: Cambridge Univ., 2018), 89-105.

${ }^{21}$ Jack Lynch, “Johnson Goes to War,” in Samuel Johnson Among the Modernists, ed. Anthony W. Lee (Clemson: Clemson Univ., 2019), 116. 
${ }^{22}$ See J. T. Scanlan, “Johnson's Dictionary and Legal Dictionaries," in Samuel Johnson's "Dictionary" and the Eighteenth-Century World of Words, ed. Giovanni Iamartino and Robert DeMaria Jr., Textus: English Studies in Italy 19 (2006): 87-106.

${ }^{23}$ See “war (n.)," in Johnson's Dictionary, sense 1.

${ }^{24}$ See Lynda Mugglestone, Samuel Johnson and the Journey into Words. (Oxford: Oxford Univ., 2015), 75-76.

${ }^{25}$ See “alert (adj.)," in Johnson's Dictionary, senses 1 and 2.

${ }^{26}$ See “mine (n.)," in Johnson's Dictionary, sense 2.

${ }^{27}$ Compare "buff (n.)," Dictionary (1755), sense 1: "A sort of leather prepared from the skin of the buffalo; used for waist belts, pouches, \&c," and "buff (n.) in Johnson's Dictionary (1773), sense 1: "A sort of leather prepared from the skin of the buffalo; used for waist belts, pouches, and military accoutrements'. See also "chief (n.)," Dictionary (1755), sense 1: “A commander, a leader," and "chief (n.) in Dictionary (1773), sense 1: “A military commander; a leader of armies; a captain.”

${ }^{28}$ Robert DeMaria Jr., Samuel Johnson and the Life of Reading (Baltimore: Johns Hopkins Univ., 1997), xii.

${ }^{29}$ Citations that appear in the Dictionary are merely a selection from those originally marked up for transcription by the amanuenses. See James L. Clifford, Dictionary Johnson (London: Heinemann, 1980), 48. For a detailed account of Johnson's processes of annotation and the ways they can be read, see Lynda Mugglestone, "The Values of Annotation: Reading Johnson Reading Shakespeare," in Revision and Revaluation: New Essays on Samuel Johnson, ed. Anthony Lee. (Newark: Univ. of Delaware, 2018), $3-24$.

${ }^{30}$ John Richardson, "War," in Samuel Johnson in Context, ed. Jack Lynch (Cambridge: Cambridge Univ., 2012), 394. 
${ }^{31}$ Ephraim Chambers, Cyclopaedia: Or, an Universal Dictionary of Arts and Sciences (London: James and John Knapton, 1728), xvi.

${ }^{32}$ See Robert DeMaria Jr., Johnson's Dictionary and the Language of Learning (Oxford: Oxford Univ., 1986), 71-72.

${ }^{33}$ Samuel Johnson, Thoughts on the Late Transactions Respecting Falkland's Islands, in Political Writings, ed. Donald J. Greene, in vol. 10 of The Yale Edition of the Works of Samuel Johnson, gen. ed. Robert DeMaria Jr., et al. (New Haven: Yale Univ., 1977), 370, henceforth, $P W$.

${ }^{34}$ See "conflict (n.)," in Johnson's Dictionary, sense 3: "There is a kind of merry war betwixt signior Benedick and her: they never meet but there's a skirmish of wit between them.Alas! he gets nothing by that. In our last conflict, four of his five wits went halting off. Shakespeare." The same citation is included in the entry for "skirmish," sense 2.

${ }^{35}$ See "nymphish (adj.)," (1773): "Tending all to nymphish war."

${ }^{36}$ "Necessary war," a collocation that, as the accompanying citation from Atterbury points out, is not prompted by "ambition," can also be included under this head. See "out (preposition)," in Johnson's Dictionary, sense 19.

${ }^{37}$ See entries for words such as "centurion (n.)," and "charioteer (n.)"

${ }^{38}$ See "heighten (v.)," Johnson's Dictionary, sense 3: "Foreign states gave us their assistance in reducing our country to a state of peace; and which of them used their endeavours to heighten our confusions, and plunge us into all the evils of civil war? Addison's Freeholder."

${ }^{39}$ Johnson's reading, and annotation for the Dictionary in these and related entries made use of Eikon Basilike. The pourtraiture of His Sacred Majesty King Charles I. In his Solitudes and Sufferings. Rom. Viii. More than Conqueror, \&c. To which is added, The royal martyr; or, 
the life and death of the said king. Written by Richard Perencheif, D. D. one of His Majesty's

Chaplains. First published in 1648, it was reprinted in 1727 in London by D. Browne, J.

Walthoe, J. and J. Knapton, et al.

${ }^{40}$ Henri Bejoint, Tradition and Innovation in Modern English Dictionaries (Oxford:

Clarendon, 1994), 21.

${ }^{41}$ See Samuel Johnson to William Strahan, 1753, Letters, ed. Redford, 1:73.

${ }^{42}$ See also “offer (v.)," Johnson's Dictionary, sense 3: "Without offering at any other remedy, we hastily engaged in a war, which hath cost us sixty millions. Swift."

${ }^{43}$ See also the entry for "frozen (adj.)" in the Dictionary: 'What was the waste of war, what fierce alarms / Shook Asia's crown with European arms; / Ev'n such have heard, if any such there be, / Whose earth is bounded by the frozen sea. Dryden's An."

${ }^{44}$ See “fundamental (adj.)," and “combustion (n.)," Johnson's Dictionary, sense 2. War also appears in illustration of "grievousness," defined as "Sorrow; pain; calamity," with the citation: "They fled from the swords, from the drawn sword and from the bent bow, and from the grievousness of war. Is.xxi.15" (i.e., Isaiah 21:15).

${ }^{45}$ See “on (interjection)," Johnson's Dictionary.

${ }^{46}$ See references to "nervous war" in a citation from Harte added under sense 2 of “nervous (adj.)," in the 1785 sixth edition of the Dictionary: “The venal torrent, murm'ring from afar, / Whisper'd no peace to calm this nervous war; / And Philomel, the siren of the plain, / Sung soporific unisons in vain. Harte."

${ }^{47}$ Ladislav Zgusta, "History and Dictionaries," in Ladislav Zgusta, Lexicography Then and Now: Selected Essays, ed. Fredric Dolezal (Tübingen: Niemeyer, 2006), 6; Johnson, The Rambler 92 (2 February 1751), in The Rambler ed. W. J. Bate and A. B. Strauss, vol. 4 of The 
Yale Edition of the Works of Samuel Johnson, gen. ed. Robert DeMaria Jr., et al. (New Haven: Yale Univ., 1969), 122.

${ }^{48}$ See Early English Books Online (EEBO), online at < https://ezproxyprd.bodleian.ox.ac.uk:7357/e/eebogroup/ >. 